\title{
The educational power of humor on student engagement in online learning environments
}

\author{
Fatih Erdoğdu ${ }^{*}$ (D) and Ünal Çakıroğlu²
}

\author{
* Correspondence: fatih.erdogdu@ \\ beun.edu.tr; fatiherdogdu67@gmail. \\ com \\ ${ }^{1}$ Department of Computer \\ Technology, Zonguldak Bülent \\ Ecevit University, Eregli, Zonguldak, \\ Turkey \\ Full list of author information is \\ available at the end of the article
}

\begin{abstract}
The primary goal of the study is to investigate the effect of the usage of humor on behavioral, emotional, and cognitive engagement in online learning. Humorous elements were integrated into the online learning components. The mixed-method study was conducted over 14 weeks with the participation of 74 university students in an online university course. As a result, elements of humor can be integrated into materials for attention grabbing, recalling, feedback, and humor breaks. A diversity of humorous elements created a significant difference and improved behavioral engagement for course materials, discussions, and assignments. However, humorous elements did not contribute to the behavioral engagement for quizzes. It was additionally observed for emotional engagement that the use of humor created a significant difference and improved emotional engagement. As for cognitive engagement, a positive influence of the usage of humorous elements in course materials, discussions and assignments was observed.
\end{abstract}

Keywords: Behavioral engagement, Cognitive engagement, Emotional engagement, Humor, Online learning

\section{Introduction}

In recent years, online learning has been broadly preferred due to the expanding interest for diverse instructional purposes. Many higher education institutions benefit from the potential of online learning by implementing a variety of learning environments. Asynchronous online learning is preferred over other forms of online learning in the education of large masses. In asynchronous online learning, the learning process is generally conducted through course materials, quizzes, assignments, and discussion activities where students often enhance learning themselves and carry out activities with their own strategies. Challenges may create situations affecting their academic success, such as boredom (Park \& Lim, 2019), lack of interest in the course, dropout, and unwillingness to take responsibility (Kim et al., 2017). Since humor creates a nonintimidating learning atmosphere, it can contribute to students' willingness to perform the assigned tasks (Baxter \& Wilmot, 1984; Graham, 1995). The study was undertaken based on the idea that the potential of humor can be realized in online learning.

(c) The Author(s). 2021 Open Access This article is licensed under a Creative Commons Attribution 4.0 International License, which permits use, sharing, adaptation, distribution and reproduction in any medium or format, as long as you give appropriate credit to the original author(s) and the source, provide a link to the Creative Commons licence, and indicate if changes were made. The images or other third party material in this article are included in the article's Creative Commons licence, unless indicated otherwise in a credit line to the material. If material is not included in the article's Creative Commons licence and your intended use is not permitted by statutory regulation or exceeds the permitted use, you will need to obtain permission directly from the copyright holder. To view a copy of this licence, visit http://creativecommons.org/licenses/by/4.0/. 
Humor is a word, concept, or situation that entertains, relaxes, or makes people laugh thanks to its pleasant characteristics (Balta, 2016). In this study, humor is evaluated within the scope of humorous elements integrated into online learning components for attention grabbing, recalling, feedback, and humor breaks. Considering the relationship of humor with the learning process, Glenn (2002) asserts that humor has the potential to involve students in the learning process by focusing on the knowledge they need to learn by creating a positive, emotional, and social environment. However, the use of humor requires delicate balances, as humor directly touches the learning atmosphere (Hellman, 2007) because students may miss the focus they need for learning and concentrate on the humor instead, consequently merely having fun rather than learning. In using humor in the learning process, there are suggestions for educators to be natural, devise word games (contrast, alliteration or abbreviation), know the students well, and to accompany the humorous approach of the students. Dormann and Biddle (2006) states that humor can have a positive effect on motivation in the learning process as it can provide students with creative thinking skills while performing learning activities.

\section{Humor and student engagement in online learning}

Humor has been used by instructors in learning processes with various educational purposes for a long time. While teaching with humor theories, such as the incongruity theory, arousal relief theory and disparagement or superiority theory, state students' perceptions of humor appropriateness (Frymier, Wanzer, \& Wojtaszczyk, 2008), they do not explain the effect of humorous messages on learning (Wanzer, Frymier, \& Irwin, 2010). The incongruity theory reveals whether the humorous content is perceived as humorous by the receivers cognitively processing it. This could explain the functionality of the humorous elements used in course materials. However, it is not enough that the elements used in educational material are humorous alone, but they must also fulfill the intended learning purpose. The Instructional Humor Processing Theory (IHPT) draws a framework by revealing the relationship between humor and learning. Wanzer et al. (2010) assert that the IHPT is a framework that reveals how the humorous message is understood cognitively and emotionally in the classroom and how it affects learning. In the theory, the incongruity is recognized and resolved first in the humorous message, then the incongruous message is perceived as humor. Finally, if it is perceived as appropriate humor, learning, and retention occurs. Considering the steps offered by the theory, humor elements were added to the online learning components (OLC) in order to utilize student engagement towards online learning within the framework of attention, recall, feedback and humor break.

Asynchronous online learning requires students to take more responsibility in their learning. Within the framework of their responsibility, students share their thoughts in writing, verbally, and visually with peers and notice their mistakes. To enable students to take an active role in the learning process and to improve collaborative learning the following needs to be included (1) course materials where students realize their own learning (Swan, 2001); (2) quizzes and assignments for online assessment (Morgan \& O'Reilly, 2001); and (3) online discussions and messaging with peers (Reeves, Herrington, \& Oliver, 2002). It is very difficult to ensure active participation as the student is mostly responsible for the learning processes (Northey, Bucic, Chylinski, \& Govind, 2015). Therefore, the online learning components (OLC) should be at a level that can 
attract students' attention and facilitate their learning. It is important to use elements of humor to actively participate in online activities to develop a positive perspective to the online lesson and to motivate students. McCabe, Sprute, and Underdown (2017) stated that utilizing humor in online learning reduces the distance between people has an especially positive effect on the relationship between teacher and student, draws attention, helps to focus, and increases learning performance. Another positive effect is that it prevents students from being silent in online discussions and encourages them to write more comments (Vandergriff \& Fuchs, 2012).

Richardson and Newby (2006) suggest that online activities should be designed to improve student engagement, and to achieve this, it is useful to recognize the target group and create activities in which students can interact. Within the framework of this recommendation, the question of how to configure the OLC in online learning environments becomes more crucial. Student engagement is generally (1) the student's effort, investment, attention, and psychological progress to achieve learning (Marks, 2000); and (2) expressed as an effort in terms of time and energy in adhering to the intended instructional activities (Nakamaru, 2012). There is a common view that the definition and scope of the student engagement concept, which has been studied by researchers in different fields for the last three decades, varies according to the study subject and background (Xu, Chen, \& Chen, 2020). However, student engagement includes three main dimensions: behavioral, emotional, and cognitive (Fredricks, Blumenfeld, \& Paris, 2004). The reason why these three specific dimensions of student engagement have been identified is that all other dimensions are derived from behavioral, cognitive, and emotional engagement. In this context, humorous activities that can make students feel positive emotions can be employed thus, creating a positive learning atmosphere. Positive emotions can initiate the cognitive process by increasing motivation and facilitating understanding by maintaining attention during learning (Mayer \& Estrella, 2014). This can indicate that emotions are an essential factor for emotional and cognitive engagement. Furthermore, negative emotions also negatively affect academic performance, as well as behavioral and cognitive engagement (Ben-Eliyahu, Moore, Dorph, \& Schunn, 2018). In research on engagement, it has been found that it is possible to enrich the learning environment by developing interventions and engagement using diverse approaches. Studies on humor determined that it makes the learner's interaction with the elements in the learning process easy and pleasant. Humor can capture students' interest, reduce feelings of boredom, increase motivation and interest, encourage risk taking, and facilitate problem solving (Lei, Cohen, \& Russler, 2010). In addition, humor can strengthen the relationship between people, reduce social distance, and create a nonintimating learning environment (Graham, 1995).

\section{The need for the study}

The rate of dropouts, lack of engagement, and many other problems in active learning has persisted in the online learning process (Jacobsen, 2019). Instructional designers and educators can include elements that improve academic achievement, interest, and a sense of community to the online learning process. In this study, elements of humor were integrated into the online learning environment and it was attempted to enhance student engagement. One of the reasons why humorous elements are preferred is that students have difficulty in developing positive emotions in online environments and 
their motivation decreases accordingly (Yang, Lavonen, \& Niemi, 2018). Consequently, this situation may prevent their active learning. At this point, humor can be considered as a useful tool for online environments with its emotional dimension. Some researchers state that humor is indispensable in learning environments. James (2004) asserts that if an educator ignores humor in online classes, it may harm the atmosphere of the online learning and negatively affect the sense of community, learning experiences, and student engagement. Considering that humor is recommended for online lessons in terms of participation and engagement in more difficult subject matter and courses (Hellman, 2007), it is important to integrate humorous elements into multimedia and examine the effect it has on student engagement. Although humor has a positive effect on the learning process, studies including actual implementations are quite limited. Most of the applied studies were carried out in face-to-face educational environments and focused on the teacher factor (Bieg, Grassinger, \& Dresel, 2018; Garner, 2006; Hellman, 2007). The very limited number of studies in the literature on humor usage in online learning environments indicates a gap in both research and application. It is noteworthy that the studies on humor in online learning are related to teacher-centered instruction and teachers' sense of humor. Humor studies for OLC in asynchronous environments have been neglected so studies in this direction should be deepened. Moreover, considering that the teacher's effect is limited in asynchronous online learning, studies on humorous elements, irrespective of the instructor's sense of humor, can provide valuable clues for instructional designers. Therefore, this study makes suggestions for applying humor in the components of the online learning process rather than determining how the teacher will use humor in class. Presenting the learning outcomes of student engagement with an experimental method enables the determination and interpretation of the online engagement-humor relationship. This study can offer concrete suggestions on how to embed humor elements into the basic components of online learning environments such as course material, assignments, discussions, and quizzes.

The aim of the study was to determine the effect of imbedded humorous elements in online learning components (OLC) on student engagement of course materials, discussions, quizzes, and assignments. The OLCs were presented humorously to the experimental group (EG) and presented normally to the control group (CG). For this purpose, the following research questions were answered:

- Is there a significant difference between the experimental and control groups in terms of behavioral, cognitive, and emotional engagement within the context of OLCs?

- How do humorous online learning components affect student engagement?

\section{Method}

\section{Research design}

The study was conducted within the embedded design of mixed method research where quantitative and qualitative data are collected sequentially in the embedded design, but qualitative data plays a supportive role to the other data. The quantitative data obtained by the experimental study, and the qualitative data used to explain them, were 
both analyzed. The quantitative data was obtained within the quasi-experimental design stage. The study reached a specific result by examining the differences between the two groups on student engagement in terms of the OLCs. In addition, the possible effects of humor on the relevant variables are explained with qualitative data.

\section{Sampling and participants}

The experimental $(n=37)(E G)$ and control $(n=37)(C G)$ groups were constructed considering prior knowledge and sense of humor. The study was carried out within the scope of the "Introduction to Programming" course. The groups were formed in the same way with the idea that students' prior knowledge of programming lessons playing a role in engagement. Accordingly, the equivalence of the groups was assessed based on the academic success scores of the "Introduction to Algorithms" course in the previous term (Table 1 ).

Table 1 indicates that there is no significant difference between the experimental and control groups' success scores $(p>.05)$. This shows that both groups' prior knowledge of programming is similar. In addition, students' sense of humor should be similar in terms of the equivalence of the groups, so the researchers obtained the names of the humor pages that the students follow on social media by asking them which humor pages they usually followed and selected only the students who followed the same humor pages. Then, the researchers traced their use of social media pages. According to these criteria, participants were randomly assigned to the CG or EG groups. Subsequently, the EG and CG were formed by grouping students who followed similar humor sites. Many participants follow and like the pages of similar humorous videos, humorous text expressions, memes and caricature sharing pages, and YouTubers who create humorous content. In addition, the humor styles of the participants were determined using the Humor Styles Questionnaire scale developed by Martin, Puhlik-Doris, Larsen, Gray, and Weir (2003). The highest scores were obtained for self-enhancing humor $(M=4.41)$ and social humor $(M=5.27)$. When the scores of all participants were examined one by one, each participant has the highest score of self-enhancing humor style and has the second-highest score of social humor style. For this reason, students were randomly assigned to the groups. The groups were matched through these criteria.

\section{Data collection instruments}

\section{Learning management system (LMS) log data and reports}

Moodle LMS log data and reports were used to designate behavioral, emotional, and cognitive engagement. The indicators acquired through Moodle for each type of engagement show the OLC activities that students engaged in on the system.

Indicators of student engagement were created by activating special features of the LMS. In addition, indicators for emotional engagement, such as emoticons, were created

Table 1 Introduction to algorithms course scores comparison

\begin{tabular}{lllllll}
\hline Group & $\boldsymbol{N}$ & Mean & SD & $\boldsymbol{t}$ & df & sig. \\
\hline CG & 37 & 2.62 & 2.49 & 0.656 & 72 & .514 \\
EG & 37 & 2.27 & 2.09 & & & \\
\hline
\end{tabular}


because the Moodle LMS, which has an open source structure, does not offer them. The number and level of emotional reactions were obtained through the added emoticons. The number of emotional reactions refers to the number of clicks on emoticons by the participants as an indicator of behavioral engagement, while the level of emotional reactions is related to on which emoticon participants click as an indicator of emotional engagement. By using emoticons, participants can state their likes or dislikes for the OLCs. The values of the emoticons represent the moods of the students to OLCs. In addition, the participants' comments in the discussions were qualitatively analyzed by two researchers, and the total number of textual expression was obtained by revealing the words and word patterns expressing emotion. Following the literature review, indicators that can exist in online learning environments emerged. In particular, indicators used in the study were based on those determined by Henrie, Halverson, and Graham (2015) and subsequent additions and adjustments were made according to the scope of the study. These indicators collected in the pool were discussed by experts and researchers. As a result of the evaluation, the necessary indicators were added, and indicators that could not be evaluated or obtained from the environment within the framework were removed. Figure 1 shows the final form of the indicators.

One of the reasons for selecting the indicators given in Fig. 1 is because the data provided by the Moodle LMS through data logs and reports fall within the scope of behavioral, cognitive, and emotional engagement. In addition, Henrie, Halverson, and Graham (2015) reviewed other student engagement studies and revealed indicators in creating a general framework for online environments. The data provided by the LMS, which are similar to the indicators suggested by Henrie, Halverson and Graham (2015), are selected in line with expert recommendations.

\section{Interview form}

Following the implementation, interviews were conducted to elucidate the differences in student engagement and to deepen the quantitative analysis. The interviews were

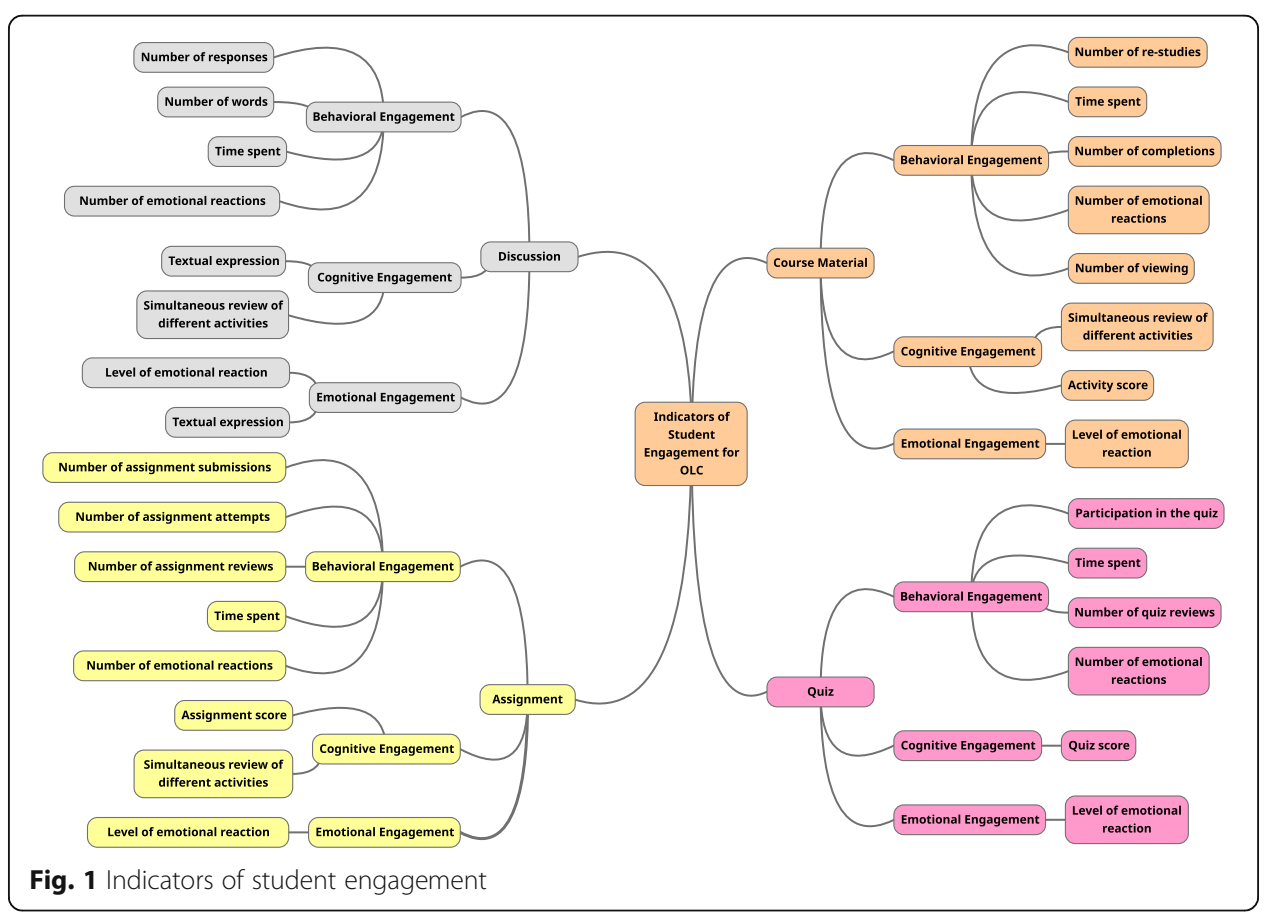


recorded in a semi-structured interview form. While designing the form, opinions of three experts (one educational technologist and two educational scientists) were received and finalized in line with their suggestions and applied to the 10 EG students. The interview form included questions regarding their engagement in accordance with the course materials, discussions, quizzes, and assignments, and also considered the indicators of behavioral, cognitive and emotional engagement.

\section{Research process}

The research process consisted of four basic stages (Fig. 2). In the preparation stage, the researchers decided on plans for design and implementation. The subjects, objectives, humorous elements, indicators of student engagement and OLCs on which the implementation will be carried out were determined as a draft. The suitability and scope of these items were evaluated by people who are competent in terms of educational technologies and humor. The preparation and design stages passed through the continuous evaluation filter, and these two stages continued cyclically until the final decision. In the design stage, the decisions taken in the first stage were transformed into

\section{Stage 1: Preparation}

- Determine the subjects and objectives

- Determine the design of the online learning components (course material, assigments, discussion activities and quiz)

- Determine the humorous elements for the components

- Determine the indicators of student engagement for online learning.

\section{Stage 2 : Design}

- Design the online learning components (OLC)

- Design the humorous elements

- Embed the humorous elements into the OLC

- Determine the interview questions
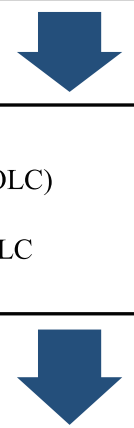

\section{Stage 3: Implementation}

- Integrate the humorous and non-humorous OLC to the LMS

- Determine the participants

- Implement the OLC experimental and control groups

- Conduct the interview

\section{Stage 4: Analysis and Evaluation}

- Analyze the quantitative data obtained from the LMS log data and reports

- Carry out the content analysis of qualitative data from the interview

- Interpret the qualitative and quantitative data

- Report the results

Fig. 2 Research process 
products. In the following stage, the 14-week implementation process was initiated by integrating the OLCs into the LMS, and at the end of the implementation, interviews were conducted. In the last stage, the researchers collected, analyzed, and interpreted the quantitative and qualitative data obtained during the implementation, and then presented the results.

\section{Embedding humorous elements into the OLCs}

The distribution of humor elements by subjects, in line with the decisions taken in the first stage, is shown in Table 2. Humor elements were applied to four different usage purposes-attention, recall, feedback, and humor break. It is stated that attracting attention in online learning environments has a positive effect on behavioral engagement. The performance of recalling and learning a subject is related to cognitive engagement, and improving motivation through feedback and providing cognitive and emotional relaxation through breaks also have a positive effect on emotional engagement. Furthermore, all three of these types of engagement are also indicators of online engagement (Henrie et al., 2015). Table 2 shows the humor elements with usage purposes and places, which can be an indicator of student engagement, that have been integrated into the OLCs in line with the suggestions of researchers in the literature.

In addition to the literature, humor elements were determined by qualitative data collected from 16 students who were not included in the experimental and control groups, and from three experts: a multimedia designer, researcher, and instructional designer in the field of humor. Since course materials require more learning processes, humor was embedded in four other different usage purposes. Humor elements in online discussions triggered the discussion both visually and textually. In the quizzes, humor elements were integrated into the root of the question and answer choices without any effect on measurement and assessment. The humor elements did not affect the comprehensibility of the questions and answers. In the assignments, the instructions were transformed into a humorous form with visual and textual expressions. Except for the course materials, humor elements embedded in the OLCs were only used for attention grabbing and recall as shown in Table 3.

Examples of humorous OLCs presented to the participants during the 14-week implementation are given in the Appendix 1, 2, 3, 4, and 5. Similar content were offered to the control group without humor. Instead of humorous elements, visual, textual, and animated contents were presented for attention grabbing, recall, feedback, and break. The way the OLCs were presented to the study groups is given in Fig. 3. A total of 14 course materials, 4 discussions, 13 assignments, and 5 quizzes were offered to the

Table 2 Humor elements and usage purposes

\begin{tabular}{|c|c|c|c|c|}
\hline & Attention & Recall & Feedback & Humor break \\
\hline Where? & In the introduction of OLCs & $\begin{array}{l}\text { Important and difficult } \\
\text { lessons or subjects }\end{array}$ & $\begin{array}{l}\text { Following the } \\
\text { activity or the } \\
\text { exam }\end{array}$ & $\begin{array}{l}\text { Following cognitive } \\
\text { fatigue }\end{array}$ \\
\hline How? & Images, caricature etc. & $\begin{array}{l}\text { Humorous text, video } \\
\text { or image }\end{array}$ & Exaggeration & $\begin{array}{l}\text { Narrative, images, } \\
\text { humorous text, joke etc. }\end{array}$ \\
\hline Who? & $\begin{array}{l}\text { (Fredrickson \& Branigan, 2005; } \\
\text { Shatz \& LoSchiavo, 2006) }\end{array}$ & $\begin{array}{l}\text { (Garner, 2006; James, } \\
\text { 2004; Lei et al., 2010) }\end{array}$ & (Berk, 2000) & $\begin{array}{l}\text { (Garner, 2006; Kher, } \\
\text { Molstad, \& Donahue, } \\
\text { 1999) }\end{array}$ \\
\hline
\end{tabular}


Table 3 Distribution of humor elements by subjects

\begin{tabular}{|c|c|c|c|c|}
\hline \multirow[t]{2}{*}{ Topics } & \multicolumn{4}{|l|}{ Humor elements } \\
\hline & Attention & Recall & Feedback & Humor break \\
\hline Basic concepts & H1: animation & $\begin{array}{l}\mathrm{H} 2 \text { : image }+ \\
\text { caricature } \\
\mathrm{H} 3 \text { : caricature }+ \\
\text { humorous text }\end{array}$ & $\begin{array}{l}\text { H4: exaggerated } \\
\text { applause }\end{array}$ & $\begin{array}{l}\text { H5: funny visual for } \\
\text { programming }\end{array}$ \\
\hline $\begin{array}{l}\text { Variables and data } \\
\text { types }\end{array}$ & H6: animation video & $\begin{array}{l}\text { H7: image } \\
\text { H8: pun }\end{array}$ & & H9: humorous text \\
\hline $\begin{array}{l}\text { Input/output } \\
\text { overview }\end{array}$ & $\begin{array}{l}\text { H10: analogy } \\
\text { H11: pun }\end{array}$ & H12: humorous text & & $\begin{array}{l}\text { H13: irony + } \\
\text { animation }\end{array}$ \\
\hline $\begin{array}{l}\text { Output } \\
\text { (application } \\
\text { example) }\end{array}$ & H14: humorous dialog & H15: accent & & $\begin{array}{l}\text { H16: funny photo }+ \\
\text { gif }\end{array}$ \\
\hline $\begin{array}{l}\text { Input (application } \\
\text { example) }\end{array}$ & $\begin{array}{l}\text { H17: irony + animated } \\
\text { character }\end{array}$ & $\begin{array}{l}\text { H18: animated } \\
\text { character }\end{array}$ & & $\begin{array}{l}\text { H19: funny photo + } \\
\text { gif }\end{array}$ \\
\hline $\begin{array}{l}\text { Input/output } \\
\text { statements } \\
\text { reminder }\end{array}$ & H20: video + image & H21: humorous text & & \\
\hline $\begin{array}{l}\text { Selection } \\
\text { structure } \\
\text { overview }\end{array}$ & $\begin{array}{l}\text { H22: short humorous } \\
\text { video + image }\end{array}$ & H23: video narration & & $\begin{array}{l}\text { H24: corny joke }+ \\
\text { movie section }\end{array}$ \\
\hline $\begin{array}{l}\text { Selection } \\
\text { structure }\end{array}$ & H25: gif & $\begin{array}{l}\text { H26: humorous text } \\
+ \text { irony }\end{array}$ & $\begin{array}{l}\text { H27: podcast with } \\
\text { funny movie line }\end{array}$ & M28: image + gif \\
\hline Loop structure & $\begin{array}{l}\text { H29: caricature + funny } \\
\text { visual for programming } \\
\text { H30: video }\end{array}$ & $\begin{array}{l}\text { H31: humorous } \\
\text { podcast + video }\end{array}$ & $\begin{array}{l}\text { H32: podcast with } \\
\text { funny movie line }\end{array}$ & H33: photo + irony \\
\hline Arrays overview & $\begin{array}{l}\text { H34: animation video + } \\
\text { humorous text }\end{array}$ & $\begin{array}{l}\text { M35: animation } \\
\text { video + humorous } \\
\text { text }\end{array}$ & & \\
\hline $\begin{array}{l}\text { One-dimensional } \\
\text { arrays }\end{array}$ & H36: caricature & $\begin{array}{l}\text { H37: image } \\
\text { H38: humorous text }\end{array}$ & $\begin{array}{l}\text { H39: podcast with } \\
\text { funny movie line }\end{array}$ & $\begin{array}{l}\text { H40: caricature + } \\
\text { humorous } \\
\text { quotations }\end{array}$ \\
\hline
\end{tabular}

experimental and control groups during the process. In addition, a total of 67 humorous elements were embedded in all OLCs, including 40 humor elements in course materials, 4 in discussions, 13 in assignments, and 10 in quizzes.

\section{Data analysis}

The data obtained from the interviews were grouped, coded, and expressed under the themes of engagement indicators by using content analysis. Thus, similarities and differences were revealed between the two research groups. The difference between the experimental and control groups based on student engagement types was analyzed using descriptive statistics, MANOVA, ANOVA, the independent $t$ test, and the MannWhitney test.

\section{Results}

\section{The effect of humor on behavioral engagement}

Descriptive statistical results of the indicators of behavioral engagement (IBE) of the two groups in the online learning components are shown in Table 4.

Table 4 shows that the IBE scores of the EG students are higher than the CG. In Table 5, MANOVA results are given according to OLCs. 


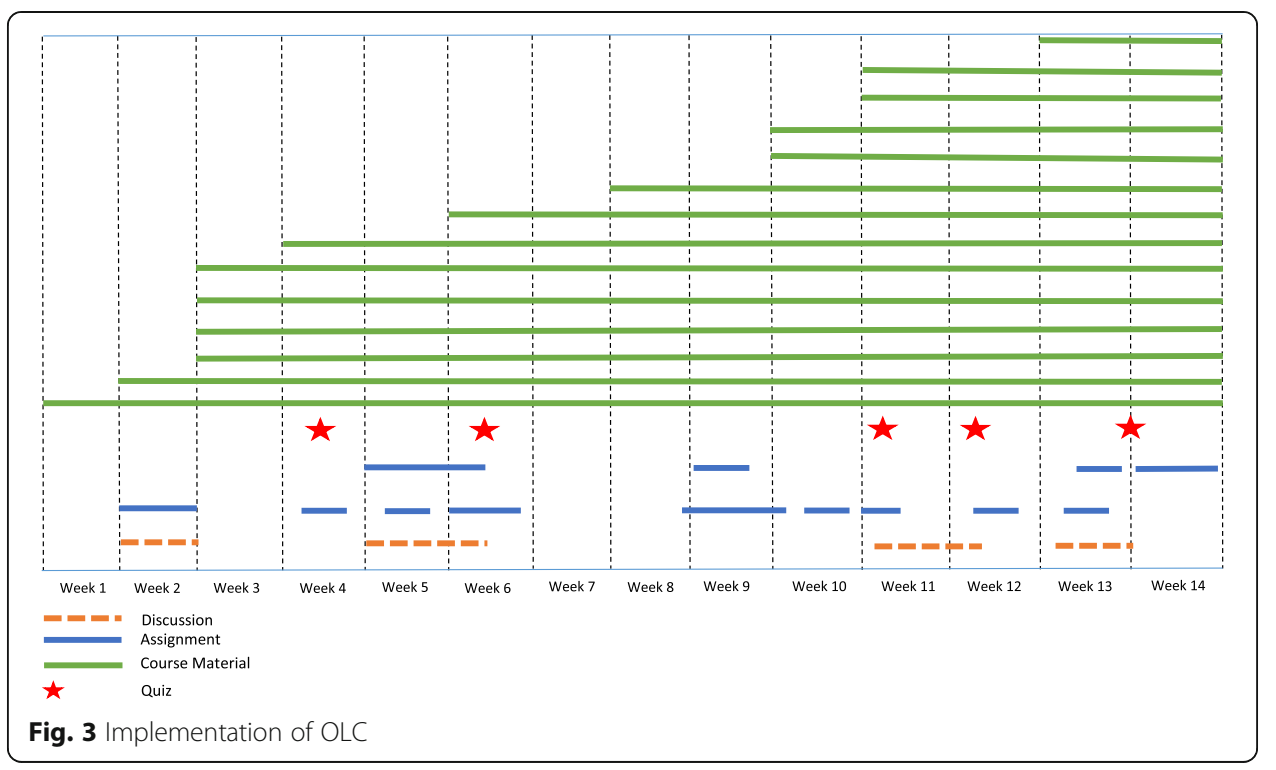

Table 5 shows that considering all the indicators between the EG and CG, there is a significant difference in terms of behavioral engagement in course materials $(\Lambda=.783, F(5$, $74)=3.77, p<.05)$, discussions $(\Lambda=.644, F(5,50)=6.22, p<.05)$, practical assignments $(\Lambda=.810, F(5,60)=2.54, p<.05)$, and the number of uploaded assignments $(\Lambda=.776$, $F(3,59)=5.283, p<.05)$. However, there is no significant difference in terms of the quizzes $(\Lambda=.949, F(4,63)=0.786, p>.05)$. The group variable has a wide impact on the dependent variables by explaining $21 \%$ of the course content, $35 \%$ of discussions, $19 \%$ of practical assignments, and $22 \%$ of uploaded assignments. An ANOVA test was performed to reveal the effect of the independent variable on the dependent variable (Table 6).

For course content, there is a significant difference between the EG and CG in terms of time spent $(F(2,74)=9.236, p<.05, \eta 2=0.114)$, number of re-studies $(F(2,74)=4.677, p<$ $.05, \mathrm{n} 2=0.061)$, and number of completions $((F(2,74)=4.430, p<.05, \mathrm{\eta} 2=.058)$. However, there is no significant difference in terms of the number of emotional reactions and the number of course material viewings $(p>.05)$. In the discussion component, whereas there is a significant difference between the groups in terms of number of responses $(F(2,50)=8.60, p<$ $.05, \mathrm{n} 2=.152)$, number of words $(F(2,50)=16.36, p<.05, \mathrm{\eta} 2=.254)$ and time spent $(F(2,50)$ $=6.78, p<.05, \mathrm{\eta} 2=.124)$ in favor of the experimental group, there is no significant difference in terms of number of emotional reactions $(p>.05)$. Moreover, in the practical assignment, a significant difference was found regarding the amount of time spent $(F(2,60)=4.402, p<.05$, $\eta 2=.071)$, and number of assignment attempts $(F(2,60)=10.558, p<.05, \eta 2=.154)$. In the uploaded assignment, there was a significant difference only with the number of assignment reviews $(F(2,59)=7.756, p<.05, \eta 2=.120)$. However, there was no significant difference in the number of assignment submissions, the number of practical assignment reviews and the number of emotional reactions in both assignments $(p>05)$. Qualitative analysis was conducted to support qualitative data and to reveal underlying causes (Fig. 4).

Humor elements have a positive effect on behavioral engagement with respect to applying on time, following, continuity, effort, focusing, active and passive participation, and the desire to apply and applying instantly, but it was observed that humor elements lead to time 
Table 4 Descriptive statistics for IBE

\begin{tabular}{|c|c|c|c|c|c|}
\hline OLC & IBE (f) & Group & $N$ & Mean & SD \\
\hline \multirow[t]{10}{*}{ Course material } & \multirow[t]{2}{*}{ Time spent (min) } & CG & 37 & 413.38 & 293.53 \\
\hline & & EG & 37 & 631.14 & 322.16 \\
\hline & \multirow[t]{2}{*}{ Study again } & CG & 37 & 41.43 & 22.68 \\
\hline & & EG & 37 & 54.54 & 29.05 \\
\hline & \multirow[t]{2}{*}{ Completion } & CG & 37 & 37.94 & 20.64 \\
\hline & & EG & 37 & 49.24 & 25.28 \\
\hline & \multirow[t]{2}{*}{ Emotional reactions } & CG & 37 & 5.86 & 4.71 \\
\hline & & EG & 37 & 7.64 & 4.39 \\
\hline & \multirow[t]{2}{*}{ Viewing } & CG & 37 & 7.51 & 6.09 \\
\hline & & EG & 37 & 7.43 & 6.007 \\
\hline \multirow[t]{8}{*}{ Discussion } & \multirow[t]{2}{*}{ Reponses } & CG & 25 & 2.28 & 1.27 \\
\hline & & EG & 25 & 3.52 & 1.68 \\
\hline & \multirow[t]{2}{*}{ Words } & CG & 25 & 74.28 & 47.79 \\
\hline & & EG & 25 & 136.44 & 60.14 \\
\hline & \multirow[t]{2}{*}{ Time spent } & CG & 25 & 30.56 & 22.33 \\
\hline & & EG & 25 & 51.64 & 33.74 \\
\hline & \multirow[t]{2}{*}{ Emotional reactions } & CG & 25 & 7.24 & 5.03 \\
\hline & & EG & 25 & 7.08 & 6.62 \\
\hline \multirow[t]{10}{*}{ Practical assignment } & \multirow[t]{2}{*}{ Assignment submissions } & CG & 30 & 5.63 & 2.67 \\
\hline & & EG & 30 & 6.03 & 2.25 \\
\hline & \multirow[t]{2}{*}{ Time spent } & CG & 30 & 66.94 & 37.03 \\
\hline & & EG & 30 & 94.20 & 60.76 \\
\hline & \multirow[t]{2}{*}{ Assignment reviews } & CG & 30 & 14.90 & 11.02 \\
\hline & & EG & 30 & 17.30 & 10.67 \\
\hline & \multirow[t]{2}{*}{ Assignment attempts } & CG & 30 & 26.76 & 21.87 \\
\hline & & EG & 30 & 47.20 & 26.60 \\
\hline & \multirow[t]{2}{*}{ Emotional reactions } & CG & 30 & 3.73 & 2.61 \\
\hline & & EG & 30 & 4.80 & 2.52 \\
\hline \multirow[t]{6}{*}{ Uploaded assignment } & \multirow[t]{2}{*}{ Assignment submissions } & CG & 29 & 2.86 & 1.21 \\
\hline & & EG & 30 & 3.06 & .98 \\
\hline & \multirow[t]{2}{*}{ Assignment reviews } & CG & 29 & 8.68 & 5.30 \\
\hline & & EG & 30 & 12.30 & 4.63 \\
\hline & \multirow[t]{2}{*}{ Emotional reactions } & CG & 29 & 3.10 & 1.20 \\
\hline & & EG & 30 & 3.00 & 1.11 \\
\hline \multirow[t]{8}{*}{ Quiz } & \multirow[t]{2}{*}{ Participation in the quiz } & CG & 30 & 3.90 & 1.53 \\
\hline & & EG & 33 & 4.09 & 1.40 \\
\hline & \multirow[t]{2}{*}{ Time spent } & CG & 30 & 54.49 & 29.65 \\
\hline & & EG & 33 & 61.44 & 28.12 \\
\hline & \multirow[t]{2}{*}{ Quiz reviews } & CG & 30 & 7.10 & 3.64 \\
\hline & & EG & 33 & 8.00 & 3.50 \\
\hline & Emotional reactions & CG & 30 & 2.86 & 1.56 \\
\hline & & EG & 33 & 2.75 & 1.22 \\
\hline
\end{tabular}


Table 5 MANOVA results for behavioral engagement

\begin{tabular}{|c|c|c|c|c|c|c|c|c|}
\hline OLC & & Effect & Value & $F$ & Hypothesis df & Error df & sig. & $\eta 2$ \\
\hline Course material & Group & Wilks' Lambda & .783 & $3.771^{\mathrm{a}}$ & 5.000 & 68.000 & .004 & .217 \\
\hline Discussion & Group & Wilks' Lambda & .644 & $6.223^{\mathrm{a}}$ & 4.00 & 45.000 & .00 & .356 \\
\hline Practical assignment & Group & Wilks' Lambda & .810 & $2.541^{\mathrm{a}}$ & 5.000 & 54.000 & .039 & .190 \\
\hline Uploaded assignment & Group & Wilks' Lambda & .776 & $5.283^{\mathrm{a}}$ & 3.000 & 55.000 & .003 & .224 \\
\hline Quiz & & Wilks' Lambda & .949 & $0.786^{\mathrm{a}}$ & 4.000 & 58.000 & .539 & .051 \\
\hline
\end{tabular}

management problems in the quiz. For example, a student who studied the course material on time, underlined: (S5) I was studying the course material a few days after the last day. The reason I studied on time was because I was curious about the jokes in the materials."

In addition, a student explains that humorous elements contribute to continuous study instead of putting off studying the material:

(S1) "For example, you have prepared a video for the "for loop". There was also a section from the movie "The Lord of the Rings" in the video. I like them very much. As I said, thanks to these humor elements, I was able to study the programming lesson repeatedly, which I really dislike, without getting bored until the end." (Time spent)

The humor elements related to behavioral engagement in the assignment especially increased student effort. A student expressed as follows: "Frankly, I was not a person who normally does homework, but I was able to do homework because I love humor. I wish all the assignments were humorous" (Number of homework attempts) (Time spent) (S10). Finally, it was concluded that while the humor elements in the quizzes help student focus and increase effort, they have no effect on participation and cause time problems.

Table 6 Results of the ANOVA test for IBE

\begin{tabular}{|c|c|c|c|c|c|c|c|c|}
\hline & Source & Dependent variable (f) & SS & df & MS & $F$ & $p$ & $\eta 2$ \\
\hline \multirow[t]{5}{*}{ Course material } & Group & Times spent (min) & 877233.09 & 1 & 877233.095 & 9.236 & .003 & .114 \\
\hline & & Re-study & 3178.716 & 1 & 3178.716 & 4.677 & .034 & .061 \\
\hline & & Completion & 2361.135 & 1 & 2361.135 & 4.430 & .039 & .058 \\
\hline & & Emotional reactions & 58.865 & 1 & 58.865 & 2.835 & .097 & .038 \\
\hline & & Viewing & .112 & 1 & .122 & .03 & .954 & .000 \\
\hline \multirow[t]{4}{*}{ Discussion } & Group & Responses & 19.220 & 1 & 19.220 & 8.600 & .005 & .152 \\
\hline & & Words & 48298.320 & 1 & 48298.320 & 16.366 & .000 & .254 \\
\hline & & Time spent & 5554.580 & 1 & 5554.580 & 6.784 & .012 & .124 \\
\hline & & Emotional reactions & 0.320 & 1 & 0.320 & 0.009 & .924 & .000 \\
\hline \multirow[t]{5}{*}{ Practical assignment } & Group & Assignment submissions & 2.400 & 1 & 2.400 & 0.393 & .533 & .007 \\
\hline & & Time spent & 11146.614 & 1 & 11146.614 & 4.402 & .040 & .071 \\
\hline & & Assignment reviews & 86.400 & 1 & 86.400 & .734 & .395 & .012 \\
\hline & & Assignment attempts & 6262.817 & 1 & 6262.817 & 10.558 & .002 & .154 \\
\hline & & Emotional reactions & 17.067 & 1 & 17.067 & 2.587 & .113 & .043 \\
\hline \multirow[t]{3}{*}{ Uploaded assignment } & Group & Assignment submissions & 0.617 & 1 & 0.617 & 0.508 & .479 & .009 \\
\hline & & Assignment reviews & 192.205 & 1 & 192.205 & 7.756 & .007 & .120 \\
\hline & & Emotional reactions & 0.158 & 1 & 0.158 & .117 & .733 & .002 \\
\hline
\end{tabular}




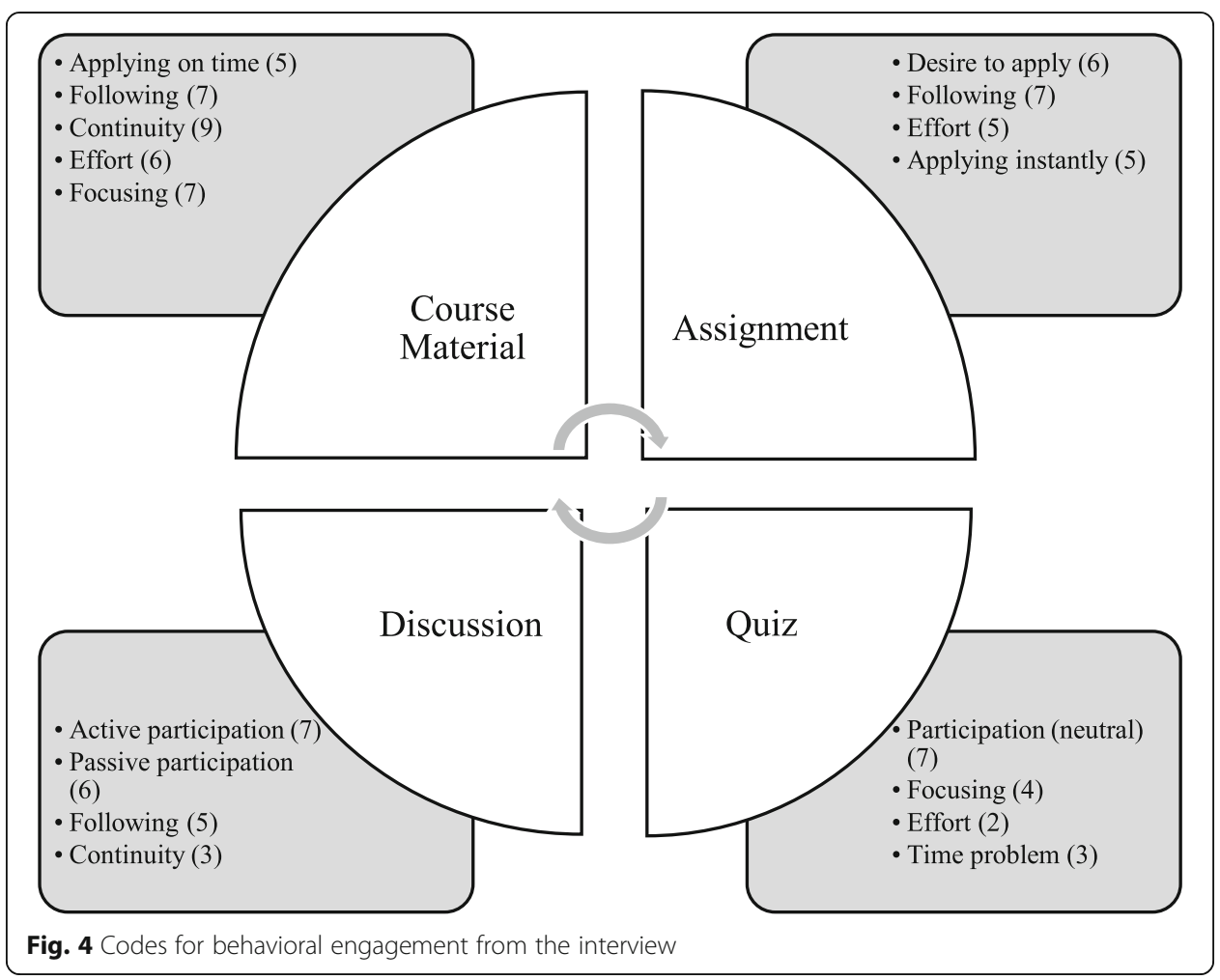

The effect of humor on cognitive engagement

The effect of humor on the indicators of cognitive engagement (ICE) was examined and Table 7 shows whether there is a significant difference in terms of the course materials, quizzes, and discussions.

Table 7 shows that the difference is significant in favor of the EG in terms of simultaneous review of different activities within the scope of the course material $(p<.05)$. However, no significant difference was found between the two groups in terms of the activity scores $(p>$ .05). In addition, there was a significant difference between the quiz scores in favor of the EG $(p<.05)$. In the discussion, while there was no significant difference in terms of textual expression $(p>05)$, it was found that there was a significant difference in terms of simultaneous review of different activities $(p<.05)$. The MANOVA and ANOVA tests were employed to reveal whether there was a significant difference between the indicators of the assignment for cognitive engagement as shown in Table 8.

Table 9 indicates that there is a significant difference between the EG and CG in terms of cognitive engagement of practical assignment $(\Lambda=.765, F(2,60)=8.760, p<$ .05). In addition, there is a significant difference in terms of cognitive engagement related to uploaded assignment $(\Lambda=.837, F(2,59)=5.456, p<.05)$. The group variable has a wide impact on dependent variables. The ANOVA test was performed to determine the source of the significant difference (Table 10).

There is a significant difference between the EG and CG in terms of the practical assignment score $(F(2,60)=15.662, p<.05, \eta 2=.213)$. In addition, a significant difference was found between the simultaneous review of various activities and the practical assignment $(F(2$, $60)=4.141, p<.05, \eta 2=.067)$. There was a significant difference between the CG and EG in terms of uploaded assignment $(F(2,59)=10.913, p<.05, \eta 2=.161)$ but no significant 
Table 7 Comparison of indicators of cognitive engagement scores

\begin{tabular}{|c|c|c|c|c|c|c|c|c|}
\hline$\overline{\mathrm{OLC}}$ & Independent variables (f) & Group & $N$ & Mean & SD & $t$ & df & sig. \\
\hline \multirow[t]{4}{*}{ Course material } & \multirow[t]{2}{*}{ Simultaneous review of different activities } & CG & 37 & 15.08 & 10.026 & \multirow[t]{2}{*}{2.978} & \multirow[t]{2}{*}{72} & \multirow[t]{2}{*}{.004} \\
\hline & & EG & 37 & 23.57 & 14.137 & & & \\
\hline & \multirow[t]{2}{*}{ Activity score } & CG & 37 & 20.45 & 7.636 & \multirow[t]{2}{*}{1.748} & \multirow[t]{2}{*}{72} & \multirow[t]{2}{*}{.085} \\
\hline & & EG & 37 & 23.78 & 8.728 & & & \\
\hline \multirow[t]{2}{*}{ Quiz } & \multirow[t]{2}{*}{ Quiz score } & CG & 30 & 72.24 & 13,23 & \multirow[t]{2}{*}{3.595} & \multirow[t]{2}{*}{61} & \multirow[t]{2}{*}{.001} \\
\hline & & EG & 33 & 83.36 & 11,29 & & & \\
\hline OLC & & Group & N & Mean rank & Sum of ranks & $U$ & & sig. \\
\hline \multirow[t]{4}{*}{ Discussion } & \multirow[t]{2}{*}{ Textual expression } & CG & 25 & 24.30 & 607.50 & \multirow{2}{*}{\multicolumn{2}{|c|}{282.500}} & .538 \\
\hline & & EG & 25 & 26.70 & 607.50 & & & \\
\hline & \multirow[t]{2}{*}{ Simultaneous review of different activities } & CG & 25 & 18.70 & 467.50 & \multirow{2}{*}{\multicolumn{2}{|c|}{142.500}} & .001 \\
\hline & & EG & 25 & 32.30 & 807.50 & & & \\
\hline
\end{tabular}

difference was found in terms of the simultaneous review of different activities with the number of uploaded assignments $(p>.05)$. In addition to the quantitative analysis, qualitative data were obtained by conducting interviews with students (Fig. 5).

Humor usage has a positive impact on cognitive engagement in the online learning environment in terms of recall, facilitating learning, redirecting to different sources, problem solving, and cognitive effort, amongst others. Besides the positive effects, however, humorous elements performed in the online quizzes resulted in disrupting student concentration. A student emphasized that humor elements in the course materials facilitate learning as follows: (S1) "I can say that I was both having fun and learning comfortably without getting bored thanks to these nice integrated things. Meanwhile, a student expressed that humor could assist in self-regulation: (S5) I studied the materials regularly throughout the semester. The reason I studied was usually to learn. In the meantime, I even logged in to watch the humor." Although humor elements help in developing different ideas and problem solving, they may cause redundant sharing in the discussion forum. A student asserts the situation: (S10) "It encourages people when there are humorous discussions. But, I am not quite sure whether it is written for learning purposes or just for entertainment."

In assignments, a student stated that humor elements help to understand the task better and increase cognitive effort:

"I was surprised and could not perceive when I met the humor at first, but I had fun with the assignment towards the end. I had laughed a lot in the "My Dream-My Life" homework. I did that homework and got a good score." (Homework Score) (S4)

It is noteworthy, however, that humorous elements can disrupt concentration in quizzes. However, as it can be seen from the student statements, humorous elements

Table 8 Descriptive statistics for assignments

\begin{tabular}{|c|c|c|c|c|c|c|c|}
\hline & \multirow[b]{2}{*}{ Group } & \multicolumn{3}{|c|}{ Practical assignment } & \multicolumn{3}{|c|}{ Uploaded assignment } \\
\hline & & $N$ & Mean & SD & $N$ & Mean & SD \\
\hline \multirow[t]{2}{*}{ Assignment score } & CG & 30 & 75.48 & 11.25 & 29 & 64.47 & 12.57 \\
\hline & EG & 30 & 85.35 & 7.74 & 30 & 75.91 & 13.96 \\
\hline \multirow[t]{2}{*}{ Simultaneous review of different activities } & CG & 30 & 5.66 & 4.18 & 29 & 3.89 & 2.35 \\
\hline & $\mathrm{EG}$ & 30 & 8.23 & 5.49 & 30 & 4.90 & 2.13 \\
\hline
\end{tabular}


Table 9 Results of the MANOVA for cognitive engagement about assignment

\begin{tabular}{lllllllll}
\hline & & Effect & Value & $\boldsymbol{F}$ & Hypothesis df & Error df & sig. & n2 \\
\hline Practical assignment & Group & Wilks' Lambda & .765 & $8.760^{\mathrm{a}}$ & 2.000 & 57,000 & .000 & .235 \\
Uploaded assignment & Group & Wilks' Lambda & .837 & $5.456^{\mathrm{a}}$ & 2.000 & 56.000 & .00 & .163 \\
\hline
\end{tabular}

can also positively affect students in giving correct responses in quizzes. In general, except from disrupting concentration in quizzes and redundant sharing in discussions, humorous elements have a positive effect on cognitive engagement.

\section{The effect of humor on emotional engagement}

An independent sample $t$ test and Mann-Whitney $U$ test were performed to measure the effect of humor on emotional engagement. The results are given in Table 11.

Table 11 shows that there is a significant difference in favor of the experimental group (emotional response levels and the number of emotional expressions) in terms of course material, assignments, discussions, and quizzes $(p<.05)$. In addition, qualitative data was obtained to support and deepen the quantitative data (Fig. 6).

Humor elements in OLCs have a positive function on attention, liking the course, reducing boredom, motivation, ice-breaking, reducing fear, and stress. There are many student expressions indicating that the uninteresting environment brought by the difficulty of programming teaching can be overcome with humor. In this context, a student underlined that humor, which is a tool for laughing and entertainment, has a positive effect on reducing boredom as follows: (S1) "I was having fun while studying, I was not bored. I would not have watched this much unless it was humorous. I could not even get on the platform sometimes." Furthermore, another student stated that humorous elements encourage her/him to comment: (S3) "I had the courage to comment because the discussion forum was humorous." Within the assignments, humorous elements can reduce the fear towards homework. Most students stated that the assignments during the course period causes negative thoughts and this fear can be eliminated by using humor. For example, a student expressed the situation as follows: (S1) "The first time the instructor uploaded some homework, we were afraid. But as I saw the humorous homework, it did not happen again. As I said before, I liked the "Nusret" humor."

Unlike behavioral and cognitive engagement, the positive effect on the quiz component was reflected by emotional engagement. It was expressed by some students that the tension before and during the quizzes could be reduced by humor. A student asserted: (S7) "We are nervous enough during the quiz. Humor makes me laugh in the quiz. I can focus more comfortably." Thus, humorous elements give a feeling of relaxation and can also reduce stress.

\section{Conclusion}

When the indicators of behavioral engagement are considered holistically, apart from the quizzes the humorous elements used in the course materials, discussions, and assignments

Table 10 Results of the ANOVA test for ICE regarding the assignments

\begin{tabular}{|c|c|c|c|c|c|c|c|c|}
\hline & Source & Dependent variable (f) & SS & df & MS & $F$ & sig. & $\eta 2$ \\
\hline \multirow[t]{2}{*}{ Practical assignment } & Group & Homework score & 1461.442 & 1 & 1461.442 & 15.662 & .000 & .213 \\
\hline & & Simultaneous review of different activities & 98.817 & 1 & 98.817 & 4.141 & .046 & .067 \\
\hline \multirow[t]{2}{*}{ Uploaded assignments } & Group & Homework score & 1930.652 & 1 & 1930.652 & 10.913 & .002 & .161 \\
\hline & & Simultaneous review of different activities & 14.848 & 1 & 14.848 & 2.945 & .092 & .049 \\
\hline
\end{tabular}




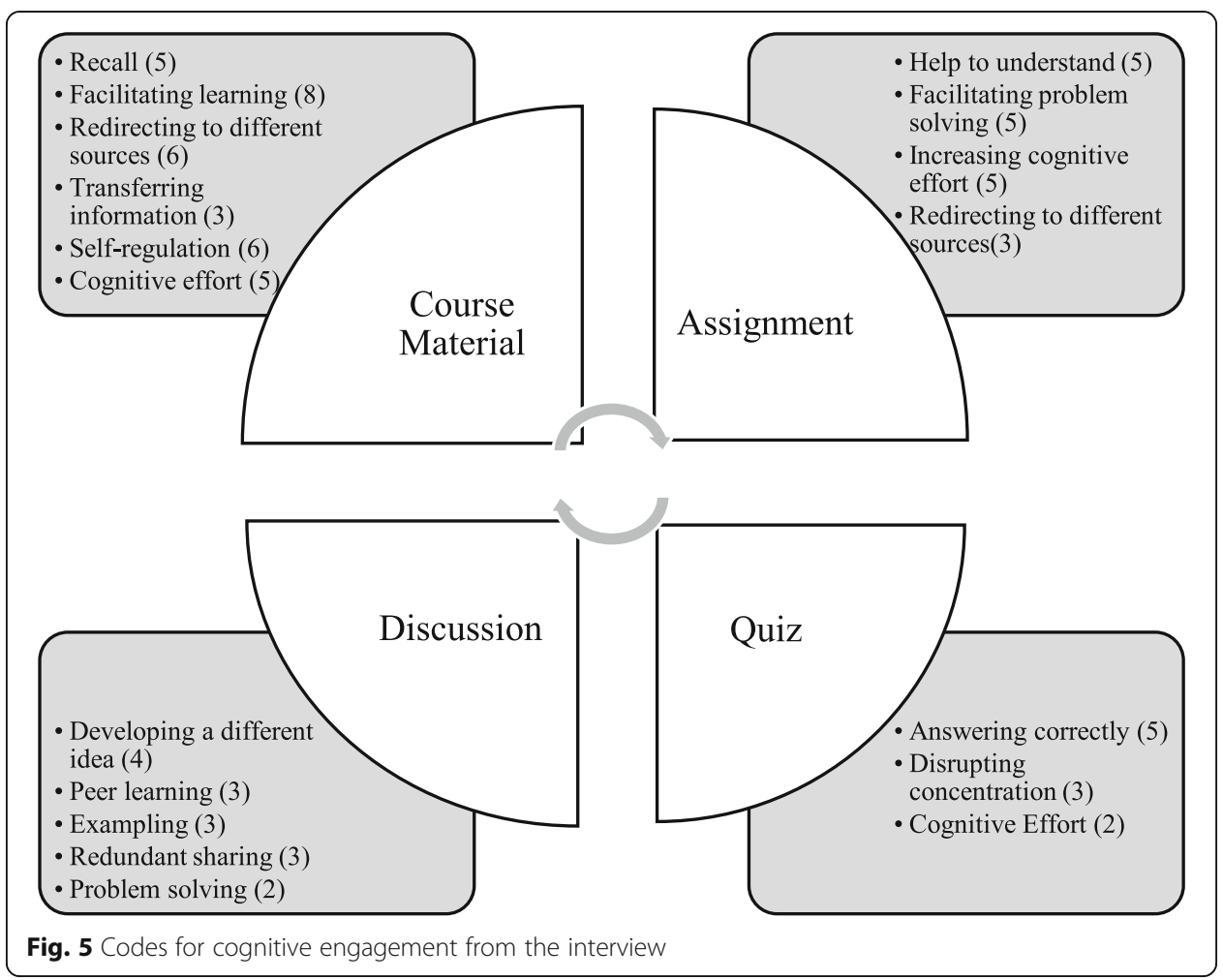

have a positive effect. Humorous elements in OLCs contribute to applying on time, following the course, continuity, focusing, and effort. In addition, humor usage has a positive effect in terms of the number of responses given by the students, the number of words, and the time spent in discussions, while it does not have any effect on the number of emotional reactions. The positive effects of humorous elements for behavioral engagement in the discussion help to maintain active participation and tracking of discussion topics. In practical assignments, the humorous element has a positive effect on the indicators of behavioral engagement, including the time spent and number of assignment attempts; but in contrast, has no effect on the number of assignment reviews, assignment submissions, and emotional

Table 11 Comparison of indicators of emotional engagement scores

\begin{tabular}{|c|c|c|c|c|c|c|c|c|}
\hline OLC & Indicators (f) & Group & $N$ & Mean & SD & $t$ & df & sig. \\
\hline \multirow[t]{2}{*}{ Course material } & Emotional reactions & $C G$ & 37 & 2.91 & 0.35 & 12.119 & 72 & 0.00 \\
\hline & & EG & 37 & 4.21 & 0.54 & & & \\
\hline \multirow[t]{3}{*}{ Uploaded assignment } & Emotional reactions & CG & 29 & 2.81 & 0.49 & 10.604 & 57 & 0.00 \\
\hline & & EG & 30 & 4.11 & 0.44 & & & \\
\hline & & Group & $\mathrm{N}$ & Mean Rank & Sum of Ranks & $U$ & & sig. \\
\hline \multirow[t]{2}{*}{ Practical assignment } & Emotional reactions & CG & 30 & 16.03 & 481.00 & 16.000 & & 0.00 \\
\hline & & EG & 30 & 44.97 & 1349.00 & & & \\
\hline \multirow[t]{4}{*}{ Discussion } & Textual expressions & CG & 25 & 19.50 & 487.50 & 162.500 & & 0.00 \\
\hline & & EG & 25 & 31.50 & 787.50 & & & \\
\hline & Emotional reactions & CG & 25 & 15.52 & 388.00 & 63.000 & & 0.00 \\
\hline & & EG & 25 & 35.48 & 887.00 & & & \\
\hline \multirow[t]{2}{*}{ Quiz } & Emotional reactions & CG & 30 & 16.03 & 481.00 & 16.000 & & 0.00 \\
\hline & & EG & 33 & 44.97 & 1349.00 & & & \\
\hline
\end{tabular}




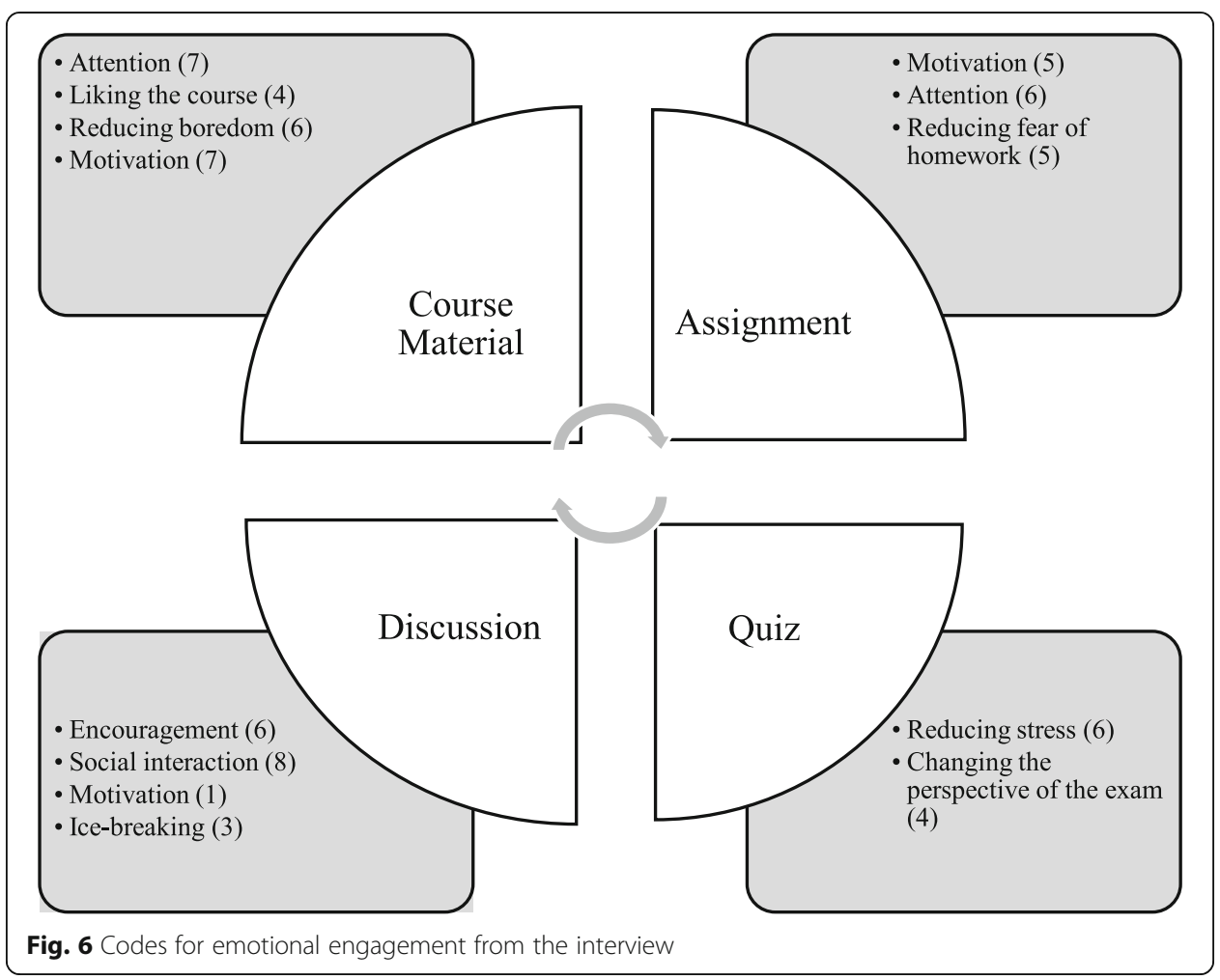

reactions. Regarding the uploaded assignment figures, a positive effect is seen on the number of assignment reviews, attempts, and emotional reactions. The humorous elements that have the potential to develop behavioral engagement related to online assignments contribute to creating a desire to do homework, providing study follow-up, encouraging effort, and completing homework in a short period of time. In the quizzes, there was no significant difference between the groups on the indicators of behavioral engagement. The humor elements used in quizzes can partially provide student focus and effort by reducing stress and anxiety but may cause time management problems during the exam.

Humorous elements improved cognitive engagement in all OLCs except for quizzes. Humor in the course material improved cognitive engagement. Humorous elements have an essential role in helping students to recall, enabling discovery, directing to different sources, sharing information with others, self-regulation, making a cognitive effort and facilitating learning. In addition, the use of humor has a partially positive effect on cognitive engagement in discussions. This effect reflects on acquiring different ideas, peer learning, exampling, and problem-solving processes. However, humorous discussions also create redundant sharing subsequently affecting cognitive engagement negatively. In assignments, humor improves cognitive engagement where it helps in understanding, facilitating problem solving, increasing cognitive effort, and redirecting to different source materials. In the quizzes, cognitive engagement developed significantly higher in the EG. As it contributes to cognitive engagement, the use of humor to reduce stress may cause partial anxiety problems because addressing the humor may disrupt student concentration. Finally, humor has the potential to improve emotional engagement in all OLCs. Humorous elements have a positive effect on attention, liking the course, reducing boredom, motivation, encouragement, social interaction, ice breaking, reducing the fear of homework, reducing stress, and in changing 
perspectives towards the exam. Figure 7 indicates the audience characteristics, the method of using humor in the application process, the structure of the programming course and the features of the humorous elements; and also shows how the features of the online learning environment affect the behavioral, emotional, and cognitive engagement of students. It was also determined that the use of humor generally contributed positively to the course under the various themes.

\section{Discussion}

Humorous elements can support achieving expected behaviors from students and ensuring their active participation in learning the content thus, providing a positive effect on learning performance. Summerfelt, Lippman, and Hyman Jr (2010) determined that the humorous elements in course material developed a positive perspective towards learning, allowing the student to spend more time in the material and to study the course materials until the end. In this study, the indicators of behavioral engagement in the course materials differ significantly in favor of the EG. Moreover, the humorous elements enabled students to put in more effort in redirecting to different activities. The student's redirection to other activities during the course study was considered as self-regulation. Self-regulation is considered to be one of the indicators of cognitive engagement (Fredricks et al., 2004). At this point, humorous elements in the course materials can provoke curiosity towards learning. Maralani (2016) designed a creative learning environment with humorous elements and found that this environment had a positive effect on cognitive, emotional, and motivational self-regulation. Garner (2006) states that the use of humor in lectures makes students recall concepts more easily. In this study,

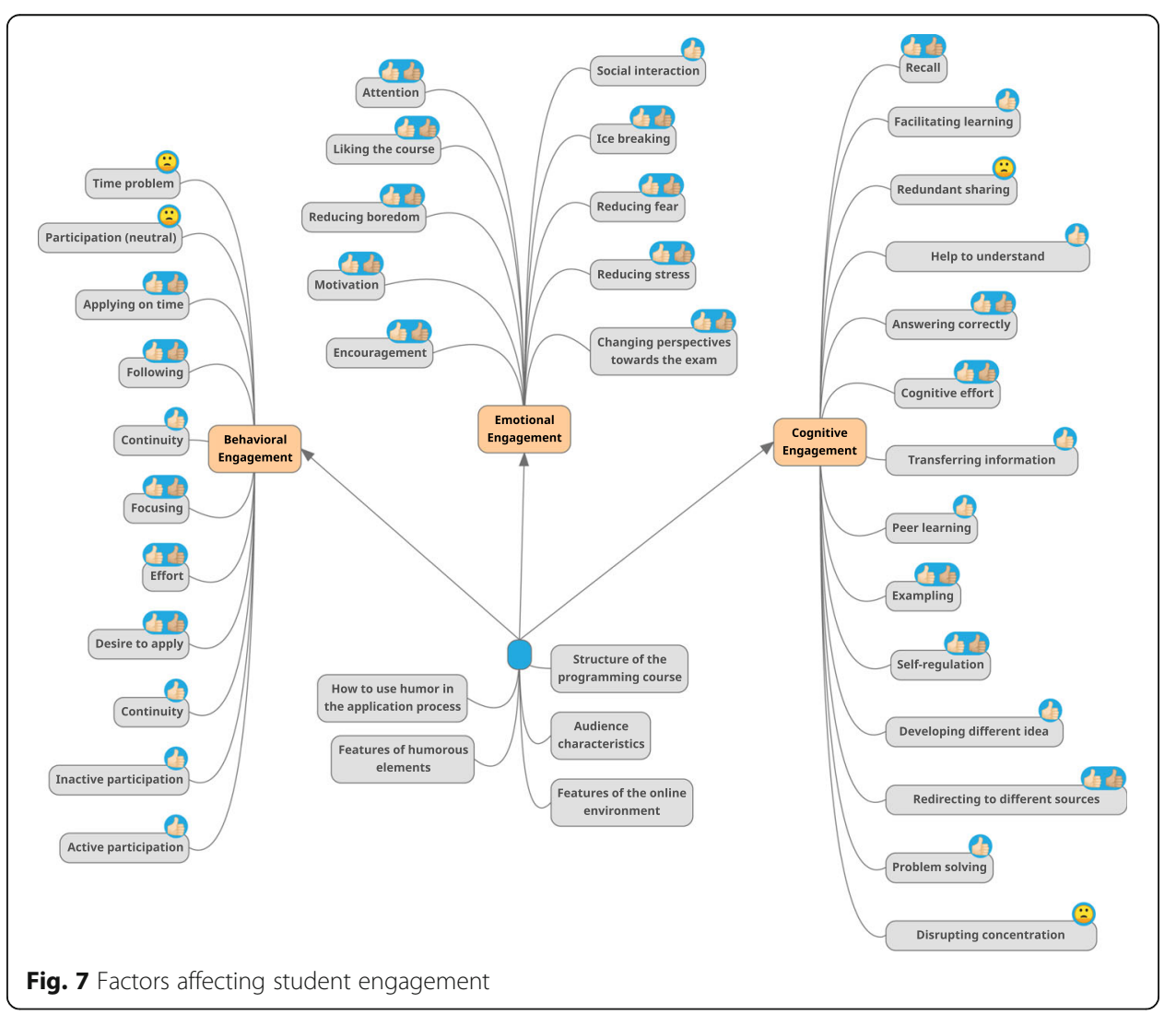


humorous textual expressions and word games integrated within the course content helped students recall.

The boredom and fatigue-reducing effect of humor can facilitate learning indirectly. Humorous elements in the course material also had a positive effect on the level of emotional reaction in terms of emotional engagement and made a significant difference in favor of the EG. This can arise due to humorous elements triggering positive emotions. Humor acts as an effective variable on a subject in learning environments and plays the role of trigger in increasing students' emotional engagement (Hoad, Deed, \& Lugg, 2013). Bieg et al. (2018) states that in performing the role of triggering these emotions, instructors are able to attract the attention of the student by using various humorous visuals, thus making it easier for students to recall. The use of humor can overcome boredom of the content (Stambor, 2006) and thus, positively change students' perspectives towards the course (Lesser, Pearl, \& Weber III, 2016). This shows that positive emotions have the feature of triggering the development of emotional engagement (King, McInerney, Ganotice Jr, \& Villarosa, 2015). Humor plays an important role in actively participating in turning the discussion environment into a natural and sincere environment, eliminating the feeling of necessity, and providing a comfortable environment akin to social media. Martin and Bolliger (2018) stated that an ice-breaking environment should be created to contribute positively to behavioral engagement in online discussions. In addition, Kara and Yildirim (2020) emphasized the importance of establishing the human element, which indicates the social aspect of interaction is the optimal behavior in online learning environments. One of the contributions of humor in online discussions is to ensure continuity in the discussion process. The positive effect of the usage of humor in discussions has been addressed similarly in various other studies; that it allows students to express themselves easily without any hesitation, and thus enables students to participate actively (Berge, 2017). Osborne, Byrne, Massey, and Johnston (2018) asserted that integrating interesting elements to the discussions would make the students wonder what kind of humor elements will be in the next discussion. Furthermore, the simultaneous participation in different activities in online learning environments is associated with self-regulation. In this study, humorous elements were perceived as a method whereby students engaged in varied activities in order to improve their learning performance. Humorous elements can also positively affect students' learning performance and their cognitive engagement. Richardson and Ice (2010) stated that the degree of comfort and confidence of discussion environments is an important factor for their high cognitive engagement. Lujan and DiCarlo (2016) state that humor positively affects engagement to the course creating a bridge for student interaction. Another result is that humor has the potential to break the ice in discussion environments. Similarly, humor breaks the ice and enables students to participate in more active learning processes (Miller et al. 2017). Moreover, Lamminpaa and Vesterinen (2018) state that humor has an essential role in social interaction during collaborative inquiry learning in discussion environments, indicating that humor has positive effects on emotional engagement in online discussions in terms of socializing, motivation, and interaction. The jokes specific to the target audience in the assignments evoked a desire to practice. Wanzer et al. (2010) emphasized that humor can motivate students and provide effort for more educational activities. Indeed, Romero and Cruthirds (2006) stated that people can engage in creative problem solving in humorous environments. It emerged from student responses that humorous assignments can make positive contributions to behavioral engagement, as humor makes us think differently and starts as fun and leads to problem solving. According to Batu, Bower, Lun, and Sadanand (2018), achievement scores in 
assignments are one of the main factors that enable cognitive progress. Self-regulation in online learning environments has a meaningful relationship in terms of three types of engagement (Sun \& Rueda, 2012). When evaluated from this perspective, it is noteworthy that the indications of self-regulation, online assignment scores, and the number of concurrent views of activities are sufficient indications of cognitive engagement. Another effect of humor usage in online assignments is that it enables students to engage in a more effort cognitively and help direct them to different source materials. However, Bolkan and Goodboy (2015) argued that students' cognitive efforts should not be increased for humor to affect cognitive learning. In this study, humor directed cognitive effort and provided cognitive engagement by affecting their cognitive learning positively. Due to the humorous elements specific to the target audience in the assignments, the assignments attracted more attention. Moreover, while humor can reduce fear and stress, it has the potential to increase self-confidence and motivation (Garner, 2006). Providing attention, motivation, and self-confidence are primary reflections of emotional engagement.

Although there were students who stated that the humorous elements in the quizzes contributed positively to their focus, there were no different developments from the control group in terms of the indicators of behavioral engagement in the quizzes. The reason why there is no significant difference between the groups in the numbers of participation in the quizzes may be because students felt obligated to participate in the quizzes irrespective of whether the quizzes have humor. Moreover, humorous elements help students to focus more easily because they break the trepidation of the exam and reduce stress thus, having a relaxing effect. These evaluations are similar to the findings of Berk (2000) who performed humorous quizzes in a face-to-face learning environment and found that different types of humorous questions reduce anxiety and stress. According to Abney, Amin, and Kibble (2017), one of the important factors affecting behavioral engagement to online quizzes is the fear that it is seen as the confirmation of failure. Similarly, in the current study, the humorous elements are thought to be overshadowed by exam anxiety. The quiz scores of the EG and CG were compared in terms of cognitive engagement in the quizzes and it was concluded that the usage of humor revealed a significant difference between the groups. Success in quizzes is seen as an indicator of students' metacognitive behavior (Abney et al., 2017). For this reason, the score in the quizzes has been determined as an indicator of cognitive engagement and the effects of humor in the course material have been observed with respect to these scores.

In this study, behavioral, cognitive, and emotional engagement was discussed in terms of course materials, class discussions, assignments, and quizzes concerning online learning. Further studies can be conducted by adding new components to cover the online learning process more thoroughly. Furthermore, future research may focus on just one component, which may provide in-depth investigation. In addition, differences in the indicators of student engagement between the two groups was examined and detailed with qualitative data. However, the study did not address indicators changing within the process. In future studies, the changes of humor effects on the indicators of the student engagement process can be observed. The effect of student engagement was examined using humor elements for four different usage purposes: attention, recall, feedback, and humor break. Online engagement can be further investigated by examining a variety of usage purposes of humor elements. Finally, the number of student engagement indicators can be increased, or it can be reduced to focus on a specific subject. 
Appendix 1. Example video for "For Loop" with "Thug Life Music" (H30)

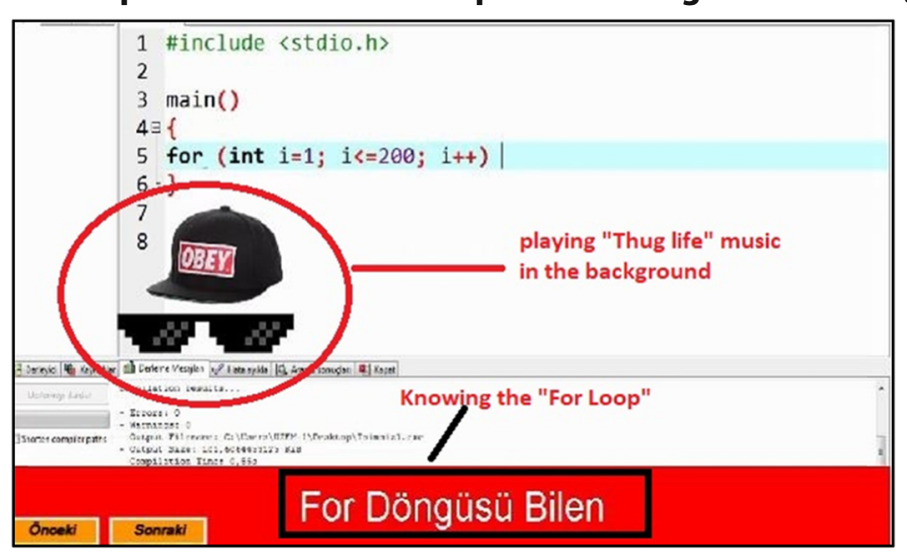

Appendix 2. Example of humorous assignment with "Nusret" character

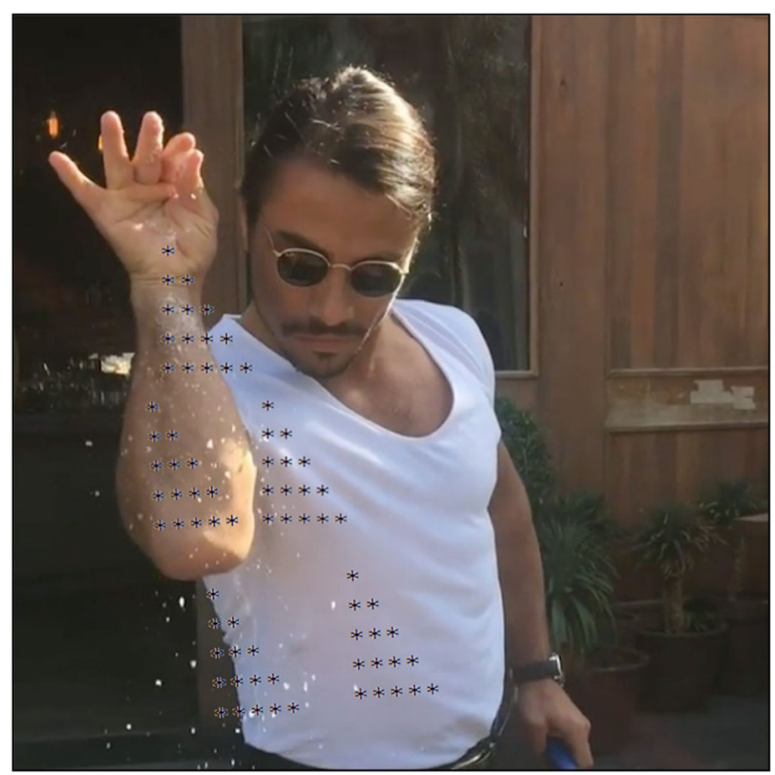


Appendix 3. Example of humorous assignment. Instructor character giving too much homework was animated by caricature

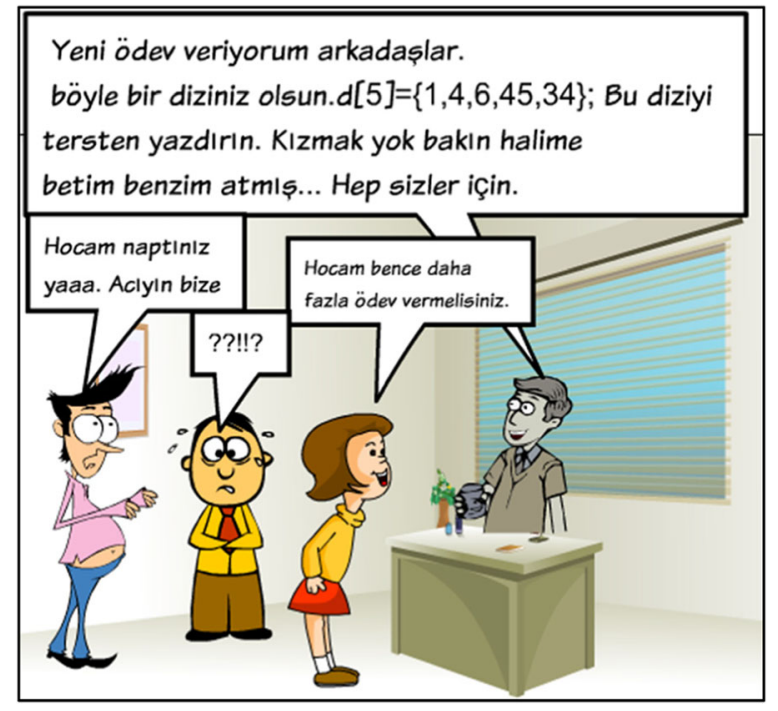

Appendix 4. Example of humorous quiz. Humorous answers do not affect measurement and assessment

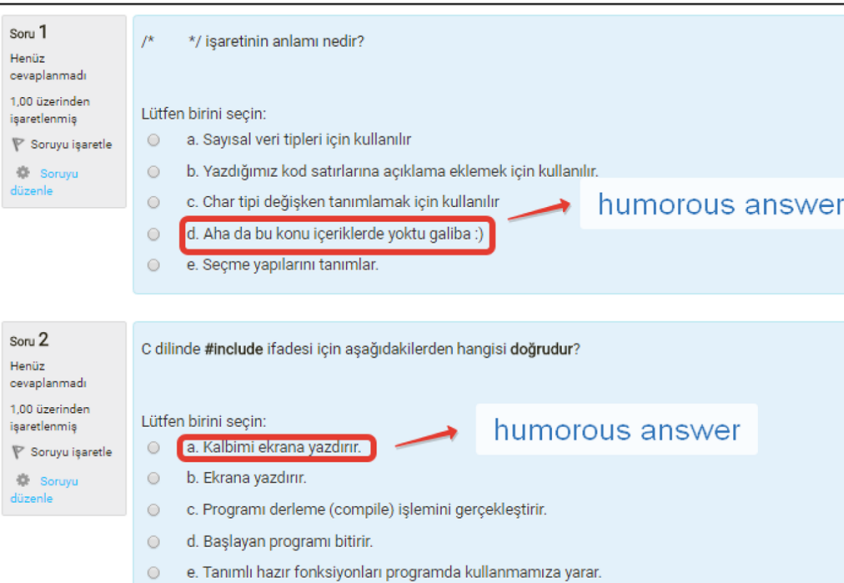




\section{Appendix 5. Example of humorous discussion}

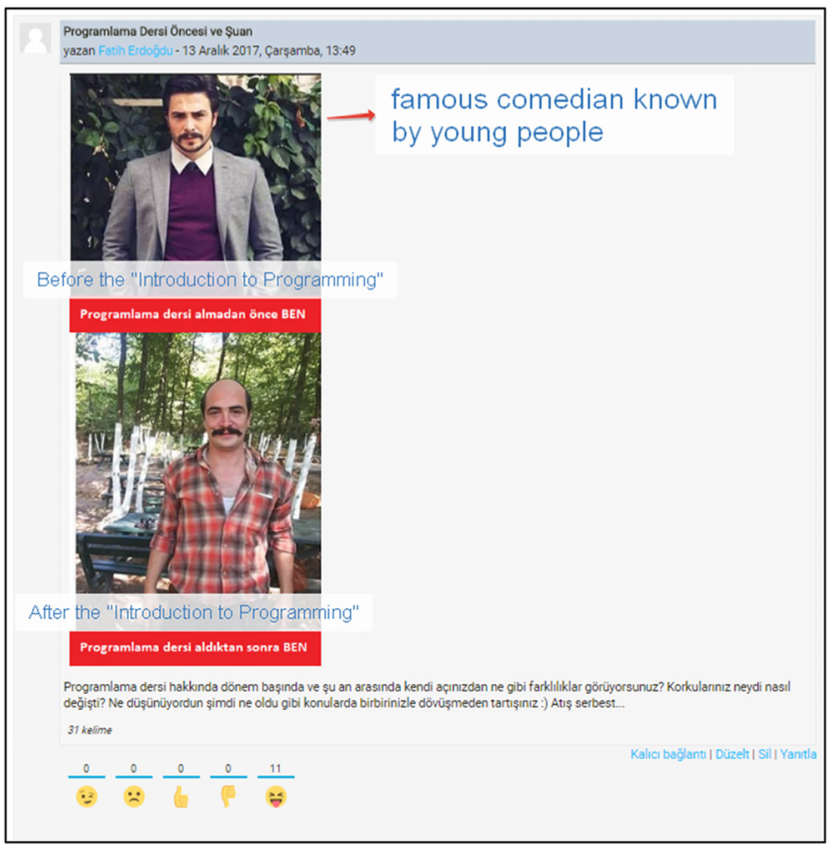

\section{Acknowledgements}

This study was derived from a part of a doctoral dissertation of the first author submitted to Karadeniz Technical University, Turkey.

\section{Authors' contributions}

Authors' contributions are equal. The author(s) read and approved the final manuscript.

\section{Funding}

Not applicable

\section{Availability of data and materials}

Not applicable

\section{Competing interests}

The authors declare that they have no competing interests.

\section{Author details}

${ }^{1}$ Department of Computer Technology, Zonguldak Bülent Ecevit University, Eregli, Zonguldak, Turkey. ${ }^{2}$ Department of

Computer Education \& Instructional Technology, Trabzon University, Trabzon, Turkey.

Received: 17 November 2020 Accepted: 4 April 2021

Published online: 26 April 2021

\section{References}

Abney, A. J., Amin, S., \& Kibble, J. D. (2017). Understanding factors affecting participation in online formative quizzes: an interview study. Advances in Physiology Education, 41(3), 457-463. https://doi.org/10.1152/advan.00074.2017.

Balta, E. E. (2016). Teachers' attitudes towards humor in education. Elementary Education Online, 15(4), 1268-1279.

Batu, M., Bower, N., Lun, E., \& Sadanand, A. (2018). Testing the effectiveness of online assignments in theory of finance. Journal of Education for Business, 93(3), 119-127. https://doi.org/10.1080/08832323.2018.1425660.

Baxter, L. A., \& Wilmot, W. W. (1984). "Secret tests" social strategies for acquiring information about the state of the relationship. Human Communication Research, 11(2), 171-201. https://doi.org/10.1111/j.1468-2958.1984.tb00044.x.

Ben-Eliyahu, A., Moore, D., Dorph, R., \& Schunn, C. D. (2018). Investigating the multidimensionality of engagement: affective, behavioral, and cognitive engagement across science activities and contexts. Contemporary Educational Psychology, 53, 87-105. https://doi.org/10.1016/j.cedpsych.2018.01.002

Berge, M. (2017). The role of humor in learning physics: a study of undergraduate students. Research in Science Education, 47(2), 427-450. https://doi.org/10.1007/s11165-015-9508-4.

Berk, R. A. (2000). Does humor in course tests reduce anxiety and improve performance? College Teaching, 48(4), 151-158. https://doi.org/10.1080/87567550009595834.

Bieg, S., Grassinger, R. \& Dresel, M. (2018). Teacher humor: longitudinal effects on students' emotions. European Journal of Psychology of Education, 34, 517-534. https://doi.org/10.1007/s10212-018-0402-0. 
Bolkan, S., \& Goodboy, A. K. (2015). Exploratory theoretical tests of the instructor humor-student learning link. Communication Education, 64(1), 45-64. https://doi.org/10.1080/03634523.2014.978793.

Dormann, C., \& Biddle, R. (2006). Humour in game-based learning. Learning, Media and Technology, 31(4), 411-424. https://doi. org/10.1080/17439880601022023.

Fredricks, J. A., Blumenfeld, P. C., \& Paris, A. H. (2004). School engagement: potential of the concept, state of the evidence. Review of Educational Research, 74(1), 59-109. https://doi.org/10.3102/00346543074001059.

Fredrickson, B. L., \& Branigan, C. (2005). Positive emotions broaden the scope of attention and thought-action repertoires. Cognition and Emotion, 19(3), 313-332. https://doi.org/10.1080/02699930441000238.

Frymier, A. B., Wanzer, M. B., \& Wojtaszczyk, A. M. (2008). Assessing students' perceptions of inappropriate and appropriate teacher humor. Communication Education, 57(2), 266-288. https://doi.org/10.1080/03634520701687183.

Garner, R. L. (2006). Humor in pedagogy: how ha-ha can lead to aha! College Teaching, 54(1), 177-180. https://doi.org/10.32 00/CTCH.54.1.177-180.

Glenn, R. (2002). Brain research: practical applications for the classroom. Teaching for Excellence., 21(6), 1-2.

Graham, E. E. (1995). The involvement of sense of humor in the development of social relationships. Communication Reports, 8(2), 158-169. https://doi.org/10.1080/08934219509367622.

Hellman, S. V. (2007). Humor in the classroom: Stu's seven simple steps to success. College Teaching, 55(1), 37-39. https://doi. org/10.3200/CTCH.55.1.37-39.

Henrie, C. R., Halverson, L. R., \& Graham, C. R. (2015). Measuring student engagement in technology-mediated learning: a review. Computers \& Education, 90, 36-53. https://doi.org/10.1016/j.compedu.2015.09.005.

Hoad, C., Deed, C. and Lugg, A. (2013). The potential of humor as a trigger for emotional engagement in outdoor education. Journal of Experiential Education, 36(1), 37-50. https://doi.org/10.1177/1053825913481583.

Jacobsen, D. Y. (2019). Dropping out or dropping in? A connectivist approach to understanding participants' strategies in an e-learning MOOC pilot. Technology, Knowledge and Learning, 24(1), 1-21. https://doi.org/10.1007/s10758-017-9298-z.

James, D. (2004). A need for humor in online courses. College Teaching, 52(3), 93-120. https://doi.org/10.3200/CTCH.52.3.93-120.

Kara, M., \& Yildirim, Z. (2020). Identification of the optimal faculty behaviors for performance improvement in distance education. Asia Pacific Education Review, 21(1), 83-97. https://doi.org/10.1007/s12564-019-09610-3.

Kher, N., Molstad, S., \& Donahue, R. (1999). Using humor in the college classroom to enhance teaching effectiveness in "dread courses". College Student Journal, 33(3), 400-403.

Kim, T. D., Yang, M. Y., Bae, J., Min, B. A., Lee, I., \& Kim, J. (2017). Escape from infinite freedom: effects of constraining user freedom on the prevention of dropout in an online learning context. Computers in Human Behavior, 66, 217-231. https:// doi.org/10.1016/j.chb.2016.09.019.

King, R. B., McInerney, D. M., Ganotice Jr., F. A., \& Villarosa, J. B. (2015). Positive affect catalyzes academic engagement: crosssectional, longitudinal, and experimental evidence. Learning and Individual Differences, 39(2), 64-72. https://doi.org/10.101 6/j.lindif.2015.03.005.

Lamminpaa, J., \& Vesterinen, V. M. (2018). The use of humour during a collaborative inquiry. International Journal of Science Education, 40(14), 1718-1735. https://doi.org/10.1080/09500693.2018.1508926.

Lei, S. A., Cohen, J. L., \& Russler, K. M. (2010). Humor on learning in the college classroom: evaluating benefits and drawbacks from instructors' perspectives. Journal of Instructional Psychology, 37(4), 326-332.

Lesser, L. M., Pearl, D. K., \& Weber III, J. J. (2016). Assessing fun items' effectiveness in increasing learning of college introductory statistics students: results of a randomized experiment. Journal of Statistics Education, 24(2), 54-62. https:// doi.org/10.1080/10691898.2016.1190190.

Lujan, H. L., \& DiCarlo, S. E. (2016). Humor promotes learning! Advances in Physiology Education, 40(4), 433-434. https://doi. org/10.1152/advan.00123.2016.

Maralani, F. M. (2016). The mediation role of intrinsic and extrinsic motivation in the relationship between creative educational environment and metacognitive self-regulation. Journal of Education and Learning, 5(3), 272-277. https://doi. org/10.5539/jel.v5n3p272.

Marks, H. M. (2000). Student engagement in instructional activity: patterns in the elementary, middle, and high school years. American Educational Research Journal, 37(1), 153-184. https://doi.org/10.3102/00028312037001153.

Martin, F., \& Bolliger, D. U. (2018). Engagement matters: student perceptions on the importance of engagement strategies in the online learning environment. Online Learning, 22(1), 205-222.

Martin, R. A., Puhlik-Doris, P., Larsen, G., Gray, J., \& Weir, K. (2003). Individual differences in uses of humor and their relation to psychological well-being: development of the humor styles questionnaire. Journal of Research in Personality, 37(1), 48-75. https://doi.org/10.1016/50092-6566(02)00534-2.

Mayer, R. E., \& Estrella, G. (2014). Benefits of emotional design in multimedia instruction. Learning and Instruction, 33(1), 12-18. https://doi.org/10.1016/j.learninstruc.2014.02.004.

McCabe, C., Sprute, K., \& Underdown, K. (2017). Laughter to learning: how humor can build relationships and increase learning in the online classroom. Journal of Instructional Research, 6, 4-7.

Miller, J. L., Wilson, K., Miller, J. and Enomoto, K. (2017). Humorous materials to enhance active learning. Higher Education Research \& Development, 36(4), 791-806. https://doi.org/10.1080/07294360.2016.1238883.

Morgan, C., \& O'Reilly, M. (2001). Innovations in online assessment. In F. E. Lockwood, \& A. Gooley (Eds.), Innovation in open \& distance learning: successful development of online and webbased learning, (pp. 179-17V). Kogan Page.

Nakamaru, S. (2012). Investment and return: Wiki engagement in a "remedial" ESL writing course. Journal of Research on Technology in Education, 44(4), 273-291.

Northey, G., Bucic, T., Chylinski, M., \& Govind, R. (2015). Increasing student engagement using asynchronous learning. Journal of Marketing Education, 37(3), 171-180. https://doi.org/10.1177/0273475315589814.

Osborne, D. M., Byrne, J. H., Massey, D. L., \& Johnston, A. N. (2018). Use of online asynchronous discussion boards to engage students, enhance critical thinking, and foster staff-student/student-student collaboration: a mixed method study. Nurse Education Today, 70, 40-46. https://doi.org/10.1016/j.nedt.2018.08.014.

Park, T., \& Lim, C. (2019). Design principles for improving emotional affordances in an online learning environment. Asia Pacific Education Review, 20(1), 53-67. https://doi.org/10.1007/s12564-018-9560-7.

Reeves, T. C., Herrington, J., \& Oliver, R. (2002). Authentic activities and online learning. 
Richardson, J. C., \& Ice, P. (2010). Investigating students' level of critical thinking across instructional strategies in online discussions. The Internet and Higher Education, 13(1-2), 52-59. https://doi.org/10.1016/j.iheduc.2009.10.009.

Richardson, J. C., \& Newby, T. (2006). The role of students' cognitive engagement in online learning. American Journal of Distance Education, 20(1), 23-37. https://doi.org/10.1207/s15389286ajde2001_3.

Romero, E. J., \& Cruthirds, K. W. (2006). The use of humor in the workplace. Academy of Management Perspectives, 20(2), $58-$ 69. https://doi.org/10.5465/amp.2006.20591005.

Shatz, M. A., \& LoSchiavo, F. M. (2006). Bringing life to online instruction with humor. Radical Pedagogy, 8(2), 1-8.

Stambor, Z. (2006). How laughing leads to learning. Monitor on Psychology, 37(6), 62-62.

Summerfelt, H., Lippman, L., \& Hyman Jr., I. E. (2010). The effect of humor on memory: constrained by the pun. The Journal of General Psychology, 137(4), 376-394. https://doi.org/10.1080/00221309.2010.499398.

Sun, J. C. Y., \& Rueda, R. (2012). Situational interest, computer self-efficacy and self-regulation: their impact on student engagement in distance education. British Journal of Educational Technology, 43(2), 191-204. https://doi.org/10.1111/j.14 67-8535.2010.01157.x.

Swan, K. (2001). Virtual interaction: design factors affecting student satisfaction and perceived learning in asynchronous online courses. Distance Education, 22(2), 306-331. https://doi.org/10.1080/0158791010220208.

Vandergriff, I., \& Fuchs, C. (2012). How to laugh online-humor support in synchronous computer-mediated communication (SCMC) HUMOR. International Journal of Humor Research, 25(4), 437-458.

Wanzer, M. B., Frymier, A. B., \& Irwin, J. (2010). An explanation of the relationship between instructor humor and student learning: Instructional humor processing theory. Communication Education, 59(1), 1-18. https://doi.org/10.1080/0363452 0903367238.

Xu, B., Chen, N. S., \& Chen, G. (2020). Effects of teacher role on student engagement in WeChat-Based online discussion learning. Computers \& Education, 157, 103956. https://doi.org/10.1016/j.compedu.2020.103956.

Yang, D., Lavonen, J. M., \& Niemi, H. (2018). Online learning engagement: Factors and results-evidence from literature. Themes in elearning, 11(1), 1-22.

\section{Publisher's Note}

Springer Nature remains neutral with regard to jurisdictional claims in published maps and institutional affiliations.

\section{Submit your manuscript to a SpringerOpen ${ }^{\circ}$ journal and benefit from:}

- Convenient online submission

- Rigorous peer review

- Open access: articles freely available online

High visibility within the field

- Retaining the copyright to your article

Submit your next manuscript at $\boldsymbol{s p r i n g e r o p e n . c o m ~}$ 